\title{
The Assessment of $\mathrm{H}_{2} \mathrm{~S}$ Emission from Araç Stream, in Karabük
}

\author{
Kadir ULUTAŞ*, Ayhan KOCAMAN, Rahman ÇALHAN \\ Karabuk University, Engineering Faculty, Department of Environmental Engineering, 78050, Karabuk, Turkey \\ (ORCID: 0000-0002-2931-3559) (ORCID: 0000-0002-1597-7936) (ORCID: 0000-0002-3894-8468)
}

\begin{abstract}
Odor pollution is an important type of pollution that is subject to complaints in terms of quality of life and health. Since the odor perception is a sensorial process that occurs naturally with breathing, it is difficult to avoid when exposed. $\mathrm{H}_{2} \mathrm{~S}$ is one of the main sources of odor pollution and wastewater reservoir, estuarine and polluted river or waterways are among the most suitable areas for $\mathrm{H}_{2} \mathrm{~S}$ formation. The aim of this study is to determine the changes in $\mathrm{H}_{2} \mathrm{~S}$ concentrations on Araç Stream. Therefore, in this study, $\mathrm{H}_{2} \mathrm{~S}$ concentrations were determined instantaneously by using portable handheld gas monitors in air samples from the surface of Araç Stream at 15 points within the boundaries of Karabük city, and at the same time, $\mathrm{pH}$ and temperature values were determined. According to results, there were statistically significant differences in the $\mathrm{H}_{2} \mathrm{~S}$ and $\mathrm{pH}$ values between the sampling points $(\mathrm{p}<0.05) . \mathrm{H}_{2} \mathrm{~S}$ concentration decreased in the order according to the sampling points as $\mathrm{SP} 10<\mathrm{SP} 1<\mathrm{SP} 11<$ $\mathrm{SP} 2<\mathrm{SP} 12<\mathrm{SP} 3<\mathrm{SP} 13<\mathrm{SP} 14<\mathrm{SP} 7<\mathrm{SP} 8<\mathrm{SP} 9<\mathrm{SP} 15<\mathrm{SP} 4<\mathrm{SP} 5<\mathrm{SP} 6$. The highest level was determined after the industrial zone and the lowest levels were determined at the furthest point from the city center and industrial facilities. The results were shown in a map by using ArcMap program of ArcGIS software package.
\end{abstract}

Keywords: Odor pollution, $\mathrm{H}_{2} \mathrm{~S}$, Araç Stream, Karabük.

\section{Karabük Araç Çayı kaynaklı $\mathrm{H}_{2} \mathrm{~S}$ Emisyonunun Değerlendirilmesi}

\section{$\ddot{O} \mathbf{z}$}

Koku kirliliği, yaşam kalitesi ve sağlık açısından şikâyet konusu olan önemli bir kirlilik türüdür. Koku algısı, nefes alma ile doğal olarak oluşan duyusal bir süreç olduğundan, maruz kaldığında kaçınılması zordur. $\mathrm{H}_{2} \mathrm{~S}$, koku kirliliğinin ana kaynaklarından biridir ve atık su rezervuarı, nehir ağzı ve kirli nehir veya suyolları $\mathrm{H}_{2} \mathrm{~S}$ oluşumu için en uygun alanlar arasındadır. Bu çalışmanın amacı Araç Çayı üzerindeki $\mathrm{H}_{2} \mathrm{~S}$ konsantrasyonlarındaki değişiklikleri belirlemektir. Bu nedenle bu çalışmada Karabük ili sınırları içerisinde 15 noktada Araç Çayı yüzeyinden alınan hava örneklerinde portatif el tipi gaz monitörleri kullanılarak anlık $\mathrm{H}_{2} \mathrm{~S}$ konsantrasyonları belirlenmiş ve aynı zamanda $\mathrm{pH}$ ve sıcaklık değerleri belirlenmiştir. Sonuçlara göre örnekleme noktaları arasında $\mathrm{H}_{2} \mathrm{~S}$ ve $\mathrm{pH}$ değerlerinde istatistiksel olarak anlamlı farklılıklar vardı $(\mathrm{p}<0,05) . \mathrm{H}_{2} \mathrm{~S}$ konsantrasyonu, örnekleme noktalarına göre sirasıyla $\mathrm{SP} 10<\mathrm{SP} 1<\mathrm{SP} 11<\mathrm{SP} 2<\mathrm{SP} 12<\mathrm{SP} 3<\mathrm{SP} 13<\mathrm{SP} 14<\mathrm{SP} 7<\mathrm{SP} 8<\mathrm{SP} 9<\mathrm{SP} 15<\mathrm{SP} 4<$ SP5< SP6 olarak azalmıştır. En yüksek seviye sanayi bölgesinden sonra, en düşük seviyeler ise şehir merkezi ve sanayi tesislerine en uzak olan noktada belirlenmiştir. Sonuçlar ArcGIS yazılım paketinin ArcMap programı kullanılarak bir haritada gösterilmiştir.

Anahtar kelimeler: Koku kirliliği, $\mathrm{H}_{2} \mathrm{~S}$, Araç Çayı, Karabük.

\section{Introduction}

Many people experience difficulties in terms of health and living comfort both in the workplace and in residential areas when exposed to different levels of hydrogen sulfide $\left(\mathrm{H}_{2} \mathrm{~S}\right)$ emissions that is the main sources of odor [1, 2]. $\mathrm{H}_{2} \mathrm{~S}$ is one of many airborne pollutants emitted by different sources such as rayon production, livestock feedlots, hog production facilities, meat processing plants, wastewater treatment

*Corresponding author: kadirulutas@karabuk.edu.tr

Recieved: 30.03.2021, Accepted: 12.08.2021 
plants, pulp and paper industry, oil and gas refining processes [3], concentrated animal feeding operations [4], wastewater sources [5], river estuary [6] and polluted river or streams [7].

Water, one of the major components of life-support environment that is part of earth is vital necessity for ecosystem [8]. However, decrease in the quality of water resources is one of the most crucial problems that negatively affect human health and quality of life. In general, water resources are polluted as a result of anthropogenic activities due to the discharge of untreated domestic and industrial wastewater, population growth, pesticides and fertilizers, organic and inorganic wastes, urban development and poor water resource management systems [7, 9, 10]. Especially the discharge of sewage system and industrial wastewater directly to the receiving water sources reduces the water quality and causes odor problems.

$\mathrm{H}_{2} \mathrm{~S}$ is one of the most important compounds that cause odor and has very serious health effects. $\mathrm{H}_{2} \mathrm{~S}$ is a colorless, flammable gas and has a strong odor of rotten eggs [3, 11]. In nature $\mathrm{H}_{2} \mathrm{~S}$ produced by decaying organic matter, is formed by the reduction of sulfate to hydrogen sulfide gas with bacteria under anaerobic conditions in septic or sewer systems [11]. $\mathrm{H}_{2} \mathrm{~S}$ can cause eye irritation, upper respiratory tract irritation, respiratory failure, and histopathological changes in the nasal cavity. It may also affect the nervous system, cardiac and vascular function, and blood pressure [3].

Since the odor perception is subjective, the odor threshold of $\mathrm{H}_{2} \mathrm{~S}$ varies between 0.01-0.3 ppm. While 1-5 ppm $\mathrm{H}_{2} \mathrm{~S}$ is a moderately offensive odor level, it may cause nausea, tearing in the eyes, headache, or sleep loss with prolonged exposure. Eye damage, indigestion and loss of appetite may occur if exposed to 20-50 ppm $\mathrm{H}_{2} \mathrm{~S}$ on a few days. Severe eye damage and lung irritation, sudden loss of consciousness within 30 minutes; and death can occur within 4-8 hours when exposed to a concentration of $500 \mathrm{ppm} \mathrm{H}_{2} \mathrm{~S}[12,13]$. Inhalation of $\mathrm{H}_{2} \mathrm{~S}$ concentrations greater than $1000 \mathrm{ppm}$ may be fatal in both humans and animals within seconds or minutes [11].

It is a fact that due to the developing industry and diversified economic activities, increasing population, the spread of irrigated agriculture, the increase in chemical fertilizers and other pesticides, both the amount of water and the water quality will be affected more negatively in the future. Thus, in this study, the $\mathrm{H}_{2} \mathrm{~S}$ pollutant formed in Araç Stream in Karabük was evaluated. The pollution load that increases due to the human activities of the stream reaches its maximum level at the Karabük outlet. Iron and steel plants, rolling mills, wastes from other industries, pesticides, domestic wastes and untreated wastewater cause the increase in pollution in the stream [14].

In addition, the pollution in the stream has caused fish deaths and annoying odors to reach serious levels [15]. However, since there is no study in the literature that determines the pollution level in Araç Stream, especially in terms of $\mathrm{H}_{2} \mathrm{~S}$, this study will fill this gap. For these reasons, the aim of this study is to determine the $\mathrm{H}_{2} \mathrm{~S}$ concentration by sampling on the surface of the Araç Stream at 15 different points and perform spatial distributions of $\mathrm{H}_{2} \mathrm{~S}$ by ArcMap program of ArcGIS software package.

\section{Material and Method}

\subsection{Study Area}

The parts of the Araç and Soğanlı Streams within the borders of Karabük constitute the study area. Araç Stream subject to this research is located in North of Turkey Westen Black Sea region, between South slope of Kure Mountains and North slopes of Ilgaz Mountains [14]. The source of the Araç Stream is the northern slopes of the Ilgaz Mountains. The total length of the Araç Stream is $150 \mathrm{~km}$, the length within Karabük is $73 \mathrm{~km}$ and flow rate is $18.714 \mathrm{~m}^{3} / \mathrm{sec}$. Soğanlı Stream originating from the southwest of Gerede. merges with Araç Stream in Karabük and takes the name Yenice River. The total length of Soğanlı Stream is $70 \mathrm{~km}$, the length within Karabük is $32 \mathrm{~km}$ and flow rate is $28.066 \mathrm{~m}^{3} / \mathrm{sec}$ [16].

\subsection{Sampling Strategy and Analysis of $\mathrm{H}_{2} \mathrm{~S}$}

It was thought that $\mathrm{H}_{2} \mathrm{~S}$ formation would be high in September due to the fact that the air temperature is above seasonal values. For this reason, although it is seen as the weak point of the study, the samples were collected one time on 14-15 September 2020. A total of 13 samples were collected from the $35 \mathrm{~km}$ long section of the Araç Stream. On the other hand, 2 samples were collected from Soğanlı Stream at a 
distance approximately $5 \mathrm{~km}$ before merging with Araç Stream. A total of 15 samples were collected at distances ranging from 0.5-10 km. Sampling points (SP) are shown in Figure 1. Air sample was taken from the water surface by using apparatus with a $25 \mathrm{~cm}$ diameter as a flux chamber, and highly sensitive digital portable measuring devices with $550 \mathrm{ml} / \mathrm{min}$ flow rate (GEOTECH BIOGAS 5000 - Portable Gas Analyzer) were used for $\mathrm{H}_{2} \mathrm{~S}$ measurement. Measurements were carried out using portable $\mathrm{pH}$ meter to determine the water $\mathrm{pH}$ value. Water temperatures were determined using a mercury thermometer. All measurements were carried out instantaneously at the sampling points and recorded. The results were shown in a map by using ArcMap program of ArcGIS software package.

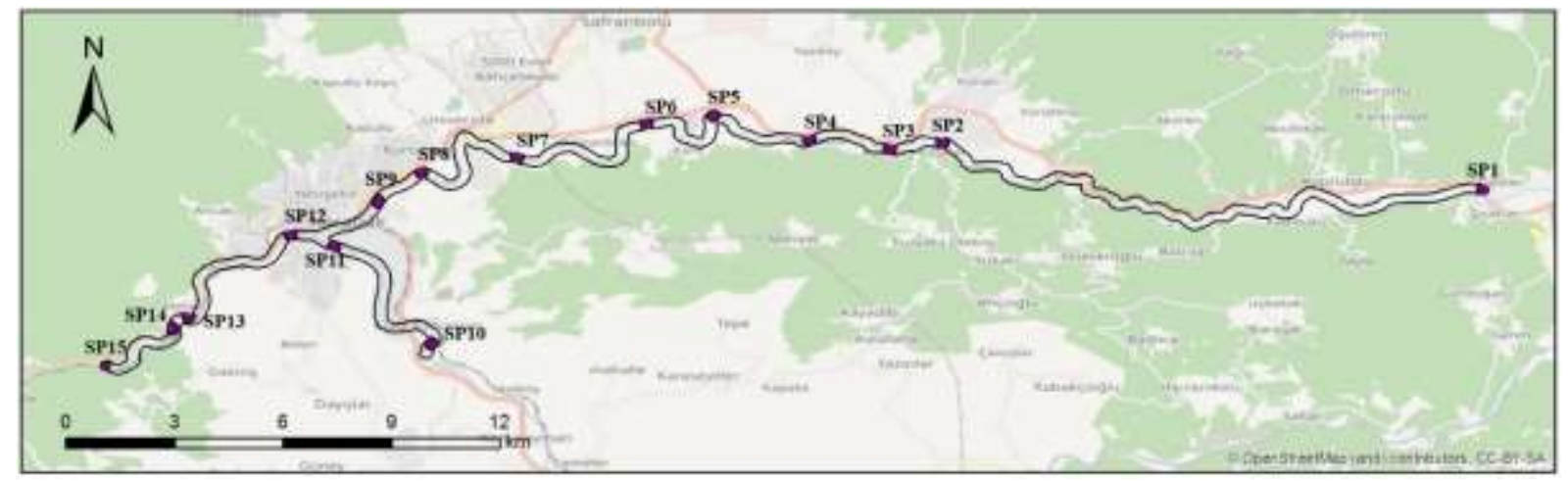

Figure 1. Sampling points

\subsection{Statistical Analyzes}

IBM SPSS 22 statistic Data Editor was used in the statistical analysis of the results obtained. The Levene trial was used for normal distribution and homogeneity of deviations, so that the mean values of the $\mathrm{H}_{2} \mathrm{~S}$ (ppm) variables taken at various pollution points along the Araç Stream and the statistical differences between pollution points are revealed. Following this, an ANOVA test was performed as there were more than two groups. Differences between measured $\mathrm{H}_{2} \mathrm{~S}$ values at 15 different points were tested using Duncan's multiple comparison analysis. In the analyses, the $\alpha$ significance level was evaluated at 0.05 .

\subsection{Spatial Distribution}

Geographical information system programs such as ArcGIS provide visual information about pollution sources and impact areas. ArcMap program of ArcGIS software package.was used to create a digital map by using values of $\mathrm{H}_{2} \mathrm{~S}$, $\mathrm{pH}$ and temperature. The coordinates of the sampling points were recorded while the samples were collected to create the distribution map. Grid, a raster GIS file format, was used to record the interpolation using the data at the sampling points. Topographic maps, satellite images and similar data of the study area were collected using GIS software GeoMedia and ArcGIS. Thus, an updatable database was created by entering the database [17].

\section{Results and Discussion}

$\mathrm{H}_{2} \mathrm{~S}$ is typically produced as a result of the degradation of sulfur-containing organic materials by bacterial activity [18]. However, parameters such as $\mathrm{pH}$, temperature, BOD, COD and DO are important variables in this process. Dissolved oxygen is necessary for organisms in metabolic processes. The amount of oxygen required by organisms in the aerobic metabolic process is represented by BOD, and the amount of chemical oxygen required for the decomposition of organic matter by chemical reaction is represented by COD. COD is also used to estimate the amount of organic matter in water [19]. In aquatic environments such as coastal areas and ports close to cities, low dissolved oxygen levels are observed due to the biological oxygen demand resulting from seasonal temperature changes [20]. The low dissolved oxygen level leads to the conversion of the aerobic environment to the anaerobic environment [19], which is a suitable environment for the formation of $\mathrm{H}_{2} \mathrm{~S}$. Temperature is an important parameter in the $\mathrm{H}_{2} \mathrm{~S}$ formation process due to its significant effect on $\mathrm{DO}$ and bacterial activity. As the temperature increases, the volatility of the liquid increases and at the same time the activities of bacteria 
in the anaerobic environment increase. It also contributes to the anaerobicity of the environment as oxygen is less soluble at high temperatures.

Sulfate ion is one of the important anions found in natural waters and wastewater. Since sulfate is used as an electron acceptor for biochemical oxidations catalyzed by anaerobic bacteria in the absence of dissolved oxygen and nitrate, the sulfate ion is reduced to $\mathrm{HS}^{-}$ion and $\mathrm{S}^{-2}$ ion under anaerobic conditions to form hydrogen sulfide (Equation 1-3).

$$
\begin{aligned}
& \mathrm{SO}_{4-}^{2}+\text { organic matter } \frac{\text { anaerobic }}{\text { bacteria }} \rightarrow \mathrm{S}^{-2}+\mathrm{H}_{2} \mathrm{O}+\mathrm{CO}_{2} \\
& \mathrm{~S}^{-2}+\mathrm{H}^{+} \leftrightarrow \mathrm{HS}^{-} \\
& \mathrm{HS}^{-}+\mathrm{H}^{+} \leftrightarrow \mathrm{H}_{2} \mathrm{~S}
\end{aligned}
$$

Different $\mathrm{pH}$ levels affect the equilibrium reaction between $\mathrm{H}_{2} \mathrm{~S}, \mathrm{HS}^{-}$and $\mathrm{S}^{-2}$. For example, if the $\mathrm{pH}$ level is 9 and above, most of the reduced sulfur is in the form of $\mathrm{HS}$ and $\mathrm{S}^{-2}$ ions, and the amount of $\mathrm{H}_{2} \mathrm{~S}$ is low. On the contrary, if the $\mathrm{pH}$ level is 9 and below, the equilibrium shifts towards the formation of un-ionized $\mathrm{H}^{2} \mathrm{~S}$ and the amount of $\mathrm{H}_{2} \mathrm{~S}$ increases [21].

Therefore, in order to determine $\mathrm{H}_{2} \mathrm{~S}, \mathrm{pH}$ and temperature values, on-site measurements were

\begin{tabular}{|c|c|c|c|c|c|c|}
\hline \multirow[b]{2}{*}{ Points } & \multicolumn{2}{|c|}{ Coordinates } & \multirow{2}{*}{ Description } & \multirow{2}{*}{$\begin{array}{c}\mathrm{H}_{2} \mathrm{~S} \\
(\mathrm{ppm})\end{array}$} & \multirow[b]{2}{*}{$\mathrm{pH}$} & \multirow{2}{*}{$\mathrm{T}\left({ }^{\circ} \mathrm{C}\right)$} \\
\hline & Latitude & Longitude & & & & \\
\hline SP1 & 41.2035 & 32.9045 & $\begin{array}{l}\text { There are no industrial facilities or heavy } \\
\text { pollutant sources }\end{array}$ & 1.00 & 7.71 & 19.00 \\
\hline SP2 & 41.2151 & 32.7703 & $\begin{array}{l}\text { There are no industrial facilities or heavy } \\
\text { pollutant sources but within the residential areas }\end{array}$ & 2.33 & 8.15 & 25.00 \\
\hline SP3 & 41.2136 & 32.7571 & $\begin{array}{l}\text { There is a residential area, restaurant and } \\
\text { shopping center. Agricultural activities are also } \\
\text { carried out }\end{array}$ & 3.00 & 8.52 & 24.00 \\
\hline SP4 & 41.2158 & 32.7372 & $\begin{array}{l}\text { It is close to the residential area and poultry farm } \\
\text { activity }\end{array}$ & 3.67 & 8.41 & 25.00 \\
\hline SP5 & 42.2219 & 32.7129 & There is no residential area and pollution source & 4.00 & 7.81 & 23.50 \\
\hline SP6 & 41.2219 & 32.7129 & $\begin{array}{l}\text { It is located after the industrial site, textile } \\
\text { production and residential area }\end{array}$ & 5.33 & 8.10 & 24.00 \\
\hline SP7 & 41.2115 & 32.6646 & $\begin{array}{l}\text { There is intensive greenhouse activities, } \\
\text { residential area and dormitory building }\end{array}$ & 3.33 & 8.24 & 28.00 \\
\hline SP8 & 41.2078 & 32.641 & $\begin{array}{l}\text { There are not residential areas however, there are } \\
\text { university and small iron and steel production } \\
\text { facilities }\end{array}$ & 3.33 & 8.19 & 24.50 \\
\hline SP9 & 41.2006 & 32.6302 & $\begin{array}{l}\text { There are not many residential areas, however } \\
\text { greenhouse cultivation activities are carried out }\end{array}$ & 3.33 & 7.85 & 24.00 \\
\hline SP10 & 41.1652 & 32.6434 & $\begin{array}{l}\text { It is located before the city center of Karabük } \\
\text { and the big iron and steel industry facility }\end{array}$ & 0.67 & 8.10 & 24.00 \\
\hline SP11 & 41.1893 & 32.6192 & $\begin{array}{l}\text { It is located after the heavy iron and steel making } \\
\text { industry }\end{array}$ & 2.00 & 8.17 & 24.00 \\
\hline SP12 & 41.1923 & 32.6084 & $\begin{array}{l}\text { It is the first point after the merger of Soğanlı } \\
\text { and Araç Stream }\end{array}$ & 2.67 & 8.17 & 27.00 \\
\hline SP13 & 41.172 & 32.583 & $\begin{array}{l}\text { Planned residential area is the majority in this } \\
\text { area and there is no sources of serious pollution }\end{array}$ & 3.00 & 8.01 & 25.00 \\
\hline SP14 & 41.1691 & 32.579 & It is located before an integrated meat facility & 3.00 & 8.03 & 27.00 \\
\hline SP15 & 41.1594 & 32.5592 & It is located after the wastwater treatment plant & 3.33 & 7.90 & 24.50 \\
\hline
\end{tabular}
carried out instantaneously triplicate at each point. Measurement results were given in Table 1.

Table 1. Values of $\mathrm{H}_{2} \mathrm{~S}$, $\mathrm{pH}$ ve Temperature

According to the results, the lowest concentration of $\mathrm{H}_{2} \mathrm{~S}$ were obtained at SP1 and SP10 as 1 ppm and 0.67 ppm respectively. SP1 was at the beginning position of the Araç Stream at the Karabük provincial border. When this point was investigated, it was seen that there were no industrial facilities 
or heavy pollutant sources nearby. SP10 was located before the city center of Karabük and the big iron and steel industry facility. In addition, it is thought that this point remained cleaner due to the presence of a dam $3.22 \mathrm{~km}$ before this point. The fact that both points were cleaner than the others is expected as they did not interact with the pollutant sources.

The third lowest $\mathrm{H}_{2} \mathrm{~S}$ concentration was at SP2, approximately $10 \mathrm{~km}$ from SP1. Although there is no industrial facility and heavy pollutant source between both points, SP2 is within the residential areas. At this point, the $\mathrm{H}_{2} \mathrm{~S}$ concentration increased $133 \%$ compared to the first point. SP3 is $11.26 \mathrm{~km}$ from SP1 and $1.26 \mathrm{~km}$ from SP2. This point is located in the area where facilities such as residential area, restaurant and shopping mall are located. In addition, agricultural activities are carried out around it. At this point, $\mathrm{H}_{2} \mathrm{~S}$ concentration increased by $29 \%$ and $200 \%$, respectively, compared to SP2 and SP1. SP4 is $13.05 \mathrm{~km}$ from SP1 and $1.79 \mathrm{~km}$ from SP3. SP4 has a higher potential for pollution than the previous point, as it is close to the residential area and poultry farm activity. At this point, $\mathrm{H}_{2} \mathrm{~S}$ concentration increased by $22 \%$ and $267 \%$, respectively, compared to SP3 and SP1. SP5 is $15.43 \mathrm{~km}$ from SP1 and $2.38 \mathrm{~km}$ from SP4. When examined between two points, it is seen that there is no residential area. In addition, there is no factor to increase the pollution level. Therefore, there is no serious difference between the two points. At this point, $\mathrm{H}_{2} \mathrm{~S}$ concentration increased by $9 \%$ and $300 \%$, respectively, compared to SP4 and SP1. Sampling point 6 is located after the industrial site, textile production and residential area. SP6 is $18.06 \mathrm{~km}$ from SP1 and $2.63 \mathrm{~km}$ from SP5. The highest concentration of $\mathrm{H}_{2} \mathrm{~S}$ was determined at the this sampling point. At this point, $\mathrm{H}_{2} \mathrm{~S}$ concentration increased by $33 \%$ and $433 \%$, respectively, compared to SP5 and SP1. SP7 is $21.52 \mathrm{~km}$ from SP1 and $3.46 \mathrm{~km}$ from SP6. It is seen that there is intensive greenhouse activities, residential area and dormitory building in this area. SP7 has $\mathrm{H}_{2} \mathrm{~S}$ lower concentration of than the previous point. At this point, $\mathrm{H}_{2} \mathrm{~S}$ concentration decreased by $-38 \%$ and increased by $233 \%$, respectively, compared to SP6 and SP1. SP8 is $25.19 \mathrm{~km}$ from SP1 and $3.67 \mathrm{~km}$ from SP7. There are not residential areas however, there are university and small iron and steel production facilities. SP8 has the same concentration of $\mathrm{H}_{2} \mathrm{~S}$ as the previous point. At this point, $\mathrm{H}_{2} \mathrm{~S}$ concentration increased by $0 \%$ and $233 \%$, respectively, compared to SP7 and SP1. SP9 is $26.42 \mathrm{~km}$ from SP1 and $1.23 \mathrm{~km}$ from SP8. Although there are not many residential areas, greenhouse cultivation activities are carried out. In addition, landscaping were made on along the stream in this area. This situation causes no change in SP9 has the same concentration of $\mathrm{H}_{2} \mathrm{~S}$ as the previous point. At this point, $\mathrm{H}_{2} \mathrm{~S}$ concentration increased by $0 \%$ and $233 \%$, respectively, compared to SP8 and SP1. SP11 is located after the heavy iron and steel making industry, and SP11 is $4.52 \mathrm{~km}$ from SP10 on the Soğanlı Stream. This sampling point is the second point on the Soğanlı Stream and the last sampling point before joining the Araç Stream. It is seen that the $\mathrm{H}_{2} \mathrm{~S}$ concentration at this point is higher than SP10. At this point, $\mathrm{H}_{2} \mathrm{~S}$ concentration increased by $199 \%$, compared to $\mathrm{SP} 10$. SP12 is $28.02 \mathrm{~km}$ from SP1, $5.18 \mathrm{~km}$ from SP10. At SP12 that is the first point after the merger of Soğanl1 and Araç Streams $\mathrm{H}_{2} \mathrm{~S}$ concentration is $2.67 \mathrm{ppm}$. This result is higher than SP11 (2.00 ppm) on the Soğanl1 Stream however, lower than the SP9 $(3.33 \mathrm{ppm})$ on the Araç Stream. SP13 is $3.94 \mathrm{~km}$ from SP12. Planned residential area is the majority in this area and there is no sources of serious pollution. At this point, $\mathrm{H}_{2} \mathrm{~S}$ concentration increased by $12 \%$ compared to SP12. The distance between SP14 and SP13 is $0.5 \mathrm{~km}$. Between these two points there is only an integrated meat facility. Although an increase in pollution is expected with this facility, fortunately there is no difference in concentration (3.00 ppm) between the two points. The distance between SP15 and SP14 is $2.18 \mathrm{~km}$. The last sampling point is located after the wastwater treatment plant. At this point, $\mathrm{H}_{2} \mathrm{~S}$ concentration increased by $11 \%$ compared to SP14.

The $\mathrm{H}_{2} \mathrm{~S}$ in gaseous form on the surface of Araç Stream passed into the atmosphere and dispersed. The spatial distribution map was prepared to show affect area of $\mathrm{H}_{2} \mathrm{~S}$ using ArcMap program of ArcGIS software package. (Figure 2). As seen in Figure 2, the effect of topography and meteorological conditions is not seen in distribution map. Meteorological, topographic and emission information are used in the air quality modeling system created with the mathematical simulation of real weather conditions in the AERMOD program. With the modeling, the change in the concentrations of the pollutants emitted from the source can be seen according to the meteorological and topographic 
changes in the study area [22]. Therefore, it will be beneficial to use the AERMOD program to create a more precise distribution map.

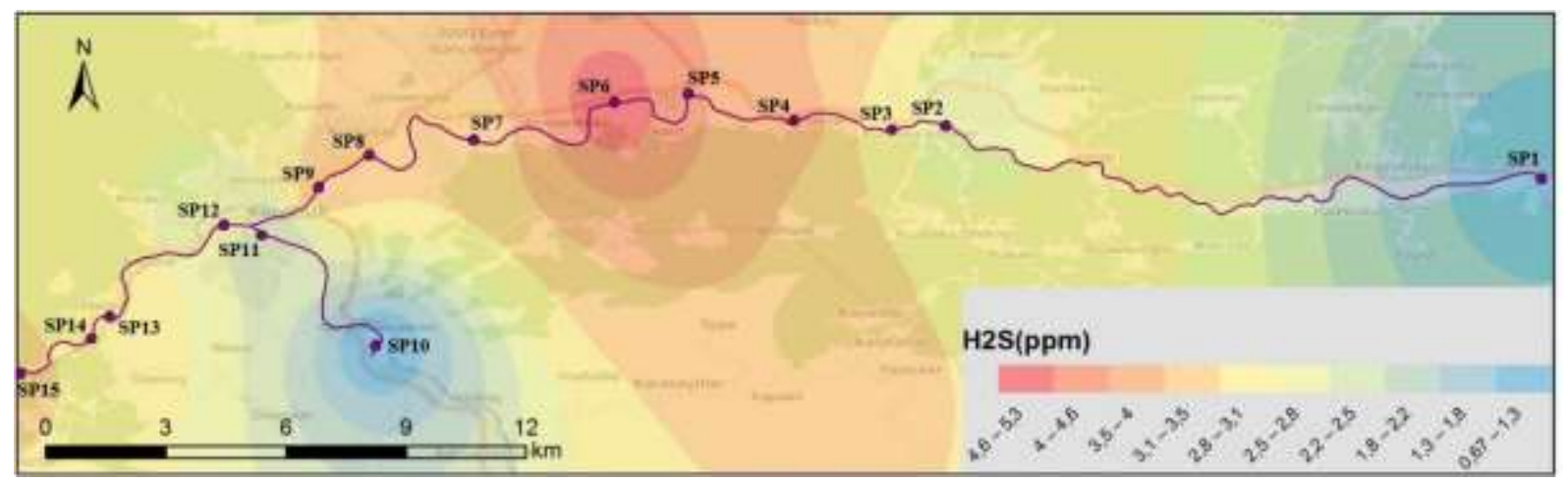

Figure 2. Distribution map of $\mathrm{H}_{2} \mathrm{~S}$

Based on the Levene test, the hypothesis that the variances were equal was confirmed, $\mathrm{F}(14.30)=256.155, \mathrm{P}=0.673$ ( $\mathrm{p}>0.05$ ) (Table 2). This is because the mean values of the $\mathrm{H}_{2} \mathrm{~S}$ (ppm) variables of different pollution points along the Araç Stream and the statistical differences between the pollution points. In the ANOVA test of group differences, the difference between points was very significant at level $\mathrm{P}<0.001$ (Table 3). In Duncan's multiple comparison analysis, there is no significant difference between the mean $\mathrm{H}_{2} \mathrm{~S}$ levels at SP7, SP8, SP9 measured at 15 different points. And SP3, $\mathrm{SP13}$, SP14 points, there is no significant difference among $\mathrm{H}_{2} \mathrm{~S}$ levels. However, it is clear that there is a significant difference between the other points measured according to the Duncan test and between points SP3, SP7, SP8, SP9, SP13, SP14 (Table 4).

Table 2. Levene Statistic Homogeneity Test

\begin{tabular}{|c|c|c|c|}
\hline \multicolumn{4}{|c|}{$\mathrm{H}_{2} \mathrm{~S}(\mathrm{ppm})$} \\
\hline $\begin{array}{c}\text { Levene Statistic } \\
0.789\end{array}$ & $\begin{aligned} \text { df1 } \\
14\end{aligned}$ & $\begin{array}{l}\mathbf{d f 2} \\
30\end{array}$ & $\begin{array}{c}\text { Sig. } \\
0.673\end{array}$ \\
\hline
\end{tabular}

Table 3. ANOVA Testing of Levels of $\mathrm{H}_{2} \mathrm{~S}$ (ppm) between Points

\begin{tabular}{ccccc}
\hline & n & df & F & Sig. \\
\hline Between Groups & 15 & 14 & 256.155 & 0.000 \\
Within Groups & 3 & 30 & & \\
Total & 45 & 44 & & \\
\hline
\end{tabular}

Table 4. Duncan multi comparison test

\begin{tabular}{llllll}
\hline Points & SP1 & SP2 & SP3 & SP4 & SP5 \\
\hline $\mathrm{H}_{2} \mathrm{~S}(\mathrm{ppm})$ Mean \pm Std & $1 \pm 0.05$ & $2.33 \pm 0.2$ & $3 \pm 0.15$ & $3.67 \pm 0.2$ & $4 \pm 0.1$ \\
Groups & $\mathrm{h}$ & $\mathrm{f}$ & $\mathrm{e}$ & $\mathrm{c}$ & $\mathrm{b}$ \\
\hline Points & SP6 & SP7 & SP8 & SP9 & SP10 \\
\hline $\mathrm{H}_{2} \mathrm{~S}(\mathrm{ppm})$ Mean \pm Std & $5.33 \pm 0.1$ & $3.33 \pm 0.1$ & $3.33 \pm 0.2$ & $3.33 \pm 0.1$ & $0.67 \pm 0.02$ \\
Groups & $\mathrm{a}$ & $\mathrm{d}$ & $\mathrm{d}$ & $\mathrm{d}$ & $\mathrm{i}$ \\
\hline Points & SP11 & SP12 & $\mathbf{S P 1 3}$ & $\mathbf{S P 1 4}$ & $\mathbf{S P 1 5}$ \\
\hline $\mathrm{H}_{2} \mathrm{~S}(\mathrm{ppm})$ Mean \pm Std & $2 \pm 0.1$ & $2.67 \pm 0.1$ & $3 \pm 0.05$ & $3 \pm 0.1$ & $3.23 \pm 0.1$ \\
Groups & $\mathrm{g}$ & $\mathrm{e}$ & $\mathrm{e}$ & $\mathrm{e}$ & $\mathrm{d}$ \\
\hline $\mathrm{P}<0.05$ & & & & &
\end{tabular}

According to the statistical analysis, statistically significant differences were found between the sampling points in $\mathrm{H}_{2} \mathrm{~S}$ and $\mathrm{pH}$ values using the SPSS Statistics program $(\mathrm{p}<0.05)$ but were not found for temperature. This result shows the effect of the properties of the sampling points on $\mathrm{H}_{2} \mathrm{~S}$ and $\mathrm{pH}$. Spatial distribution map of temperature and $\mathrm{pH}$ values is shown in Figure 3 and 4. 


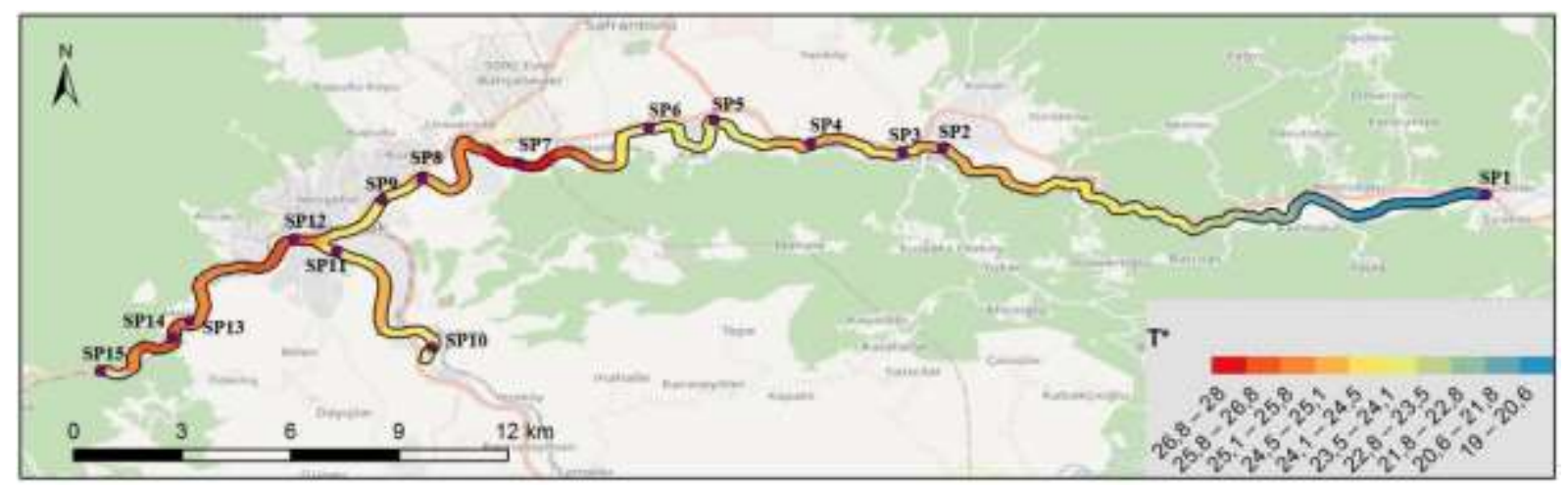

Figure 3. Temperature values $\left({ }^{* \circ} \mathrm{C}\right)$

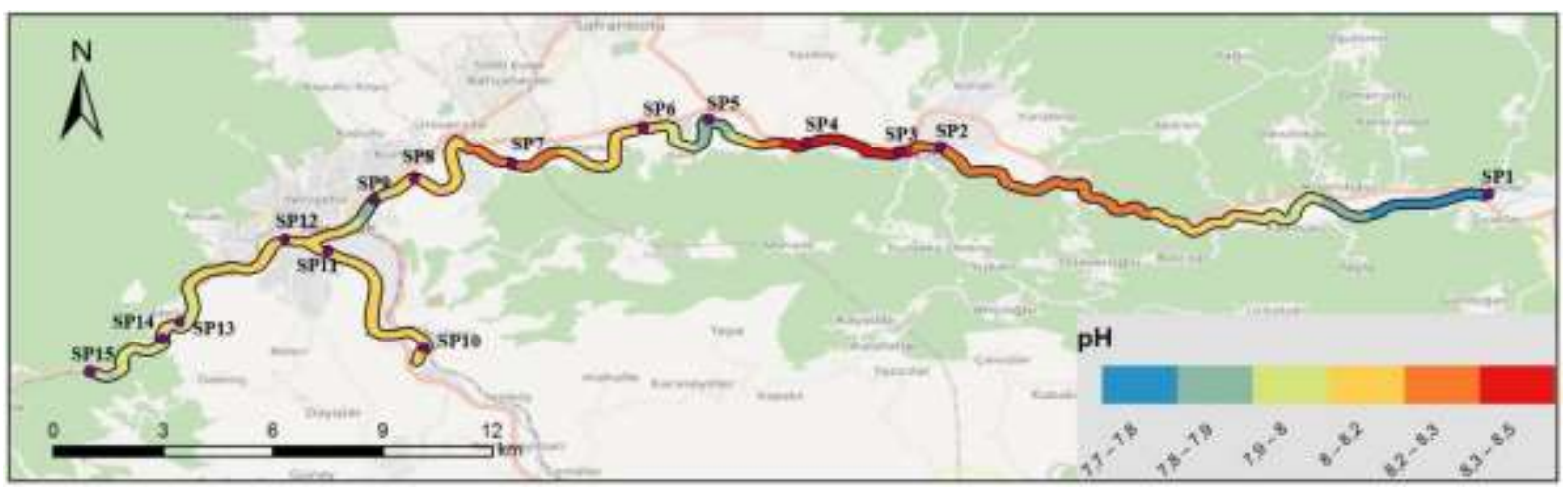

Figure 4. $\mathrm{pH}$ values

It has been stated in the study by Wiener et al. that many rivers empty into the Mexican port and the Gulf of Mexico is one of the world's largest oil producing areas. It was also emphasized in the study that $\mathrm{H}_{2} \mathrm{~S}$ formation is affected by the oxygen content of the water [20]. It has been reported in the study by Isworo et al. that Indonesian State Oil Company activity produces waste that allows pollution of the Donan river. The values of the pollutant parameters were determined to reveal the pollution level of the study area. BOD, COD, DO levels were found in the range of 5.5-7.2 ppm, 33.64-33.73, 6.01-5.90 ppm, respectively. In addition $\mathrm{H}_{2} \mathrm{~S}$ concentration was determined as $0.2 \mathrm{ppm}$ [19]. In the study conducted by Ogbemudia and Ita [6] in Lower Stubbs Creek, Qua Iboe River Estuary, Nigeria air quality was assessed with samples taken from 5 different points using portable hand held gas monitors for atmospheric gases. The concentration of $\mathrm{H}_{2} \mathrm{~S}$ ranges from $0.6 \mathrm{ppm}$ to $0.9 \mathrm{ppm}$, with an average of $0.77 \mathrm{ppm} . \mathrm{H}_{2} \mathrm{~S}$ values in both studies were found to be lower. In study by Moreno-Silva et al. [5] different $\mathrm{H}_{2} \mathrm{~S}$ emission sources were evaluated and simulated in order to determine the odor effect of the Munas reservoir in Colombia. Flux chamber was used in the study and it was figured out that in critical conditions Munas reservoir can cause an atmospheric concentration of $4 \mathrm{ppm} \mathrm{H}_{2} \mathrm{~S}$ in reservoir-surrounding urban region. This result was in the $\mathrm{H}_{2} \mathrm{~S}$ level range $(0.67-5.33 \mathrm{ppm})$ in present study due to the similarity of the method and study area. In another study by Antai et al. [23] changes in air quality was assessed in wet season in Eleme, Rivers State, Nigeria and the average concentration of $\mathrm{H}_{2} \mathrm{~S}$ was recorded as $0.37 \mathrm{ppm}$. Because the study was conducted in the rainy season, lower results may have been obtained. In the study conducted by Novita et al. [7], the water quality of the Bedadung River in Jember Regency, East Java, Indonesia was evaluated with samples taken from 5 different points, and the average concentration of $\mathrm{H}_{2} \mathrm{~S}$ was determined as $0,035 \mathrm{mg} / \mathrm{dm}^{3}$. In a study conducted in 1998 , the average sulfur concentration in river waters was found to be $180 \mathrm{mg} / \mathrm{L}$. The irritating odors caused by especially $\mathrm{H}_{2} \mathrm{~S}$ continued until the first half of 2001 where streams carried untreated domestic and industrial wastewater to İzmir Bay [24, 25]. Rim-Rukeh found $\mathrm{H}_{2} \mathrm{~S}$ concentration in the vicinity of dump site fires in the range of 3.4 to 7.7 ppm [26]. The average $\mathrm{H}_{2} \mathrm{~S}$ concentration in present study is also within this range.

Since $\mathrm{H}_{2} \mathrm{~S}$ formation is affected by water or wastewater properties such as BOD, COD, DO, pH and temperature, as well as environmental conditions such as untreated industrial or domestic wastes, and use of area such as industrial, residential or agricultural, different or close concentrations of $\mathrm{H}_{2} \mathrm{~S}$ can be detected in each study. As different land uses change the originality of the land structure [27], 
anthropogenic activities can also disrupt the structure of water and air. In this study area, there are many different anthropogenic activities such as agriculture, iron and steel industry, vehicle repair, institutional, domestic and livestock. For example, livestock is one of the most important sources of $\mathrm{H}_{2} \mathrm{~S}$. Animal waste can be a source of $\mathrm{H}_{2} \mathrm{~S}$ as a result of the degradation of biosolids, including manure and feed [28]. In addition, wastewater greatly contributes to the formation of $\mathrm{H}_{2} \mathrm{~S}$ as a result of decomposition of organic matter by microorganisms in anaerobic conditions [29]. Moreover, industrial activities can also cause $\mathrm{H}_{2} \mathrm{~S}$ pollution [30], especially in food, rubber and leather industries, odor pollution arising from raw materials and processes can be observed [31]. Although it is at a very low level compared to other e emission sources, solid waste landfills are among the most important $\mathrm{H}_{2} \mathrm{~S}$ sources [32]. Finally, $\mathrm{H}_{2} \mathrm{~S}$ is also associated with agricultural processes [33] due to the decay of the organic structure of agricultural wastes in aqueous environments such as streams. Therefore, different or close concentrations of $\mathrm{H}_{2} \mathrm{~S}$ were determined both between sampling points and other studies depending on anthropogenic activities.

\section{Conclusion and Recommendations}

In this study, the differences in atmospheric $\mathrm{H}_{2} \mathrm{~S}$ concentration along Araç Stream were determined. In addition, the spatial distribution of $\mathrm{H}_{2} \mathrm{~S}$ emissions from Araç Stream was shown in this study.

- It has been observed that closeness of residential areas, industrial sites, agricultural and industrial activities cause an increase in $\mathrm{H}_{2} \mathrm{~S}$ concentration.

- Statistically significant differences were found between the sampling points in $\mathrm{H}_{2} \mathrm{~S}$ and $\mathrm{pH}$ values using the SPSS Statistics program ( $\mathrm{p}<0.05$ ), but were not found for temperature.

- In pariticular, it was observed that the $\mathrm{H}_{2} \mathrm{~S}$ level was higher at the sampling points after the places where the untreated water was given to the Araç Stream.

- It was determined that the measurements were above the odor threshold value.

- In addition, since the $\mathrm{H}_{2} \mathrm{~S}$ concentraions are generally between 1-5 ppm, prolonged exposure may adversely affect health and quality of life.

- Since there are no topographic and meteorological effects in the spatial distribution map by ArcMap program of ArcGIS software package, it will be useful to use programs such as AERMOD to create a more precise distribution map.

$\mathrm{H}_{2} \mathrm{~S}$ has not been measured in Araç Stream before. For this reason, it can be used as an important data source in the evaluations to be made about whether the pollution load will increase in the future.It is also expected to contribute to the literature as a data source that can be used for comparison in similar studies conducted in different streams. As a result, it was observed that $\mathrm{H}_{2} \mathrm{~S}$ was spread from the Araç Stream but was not effective in residential areas due to atmospheric dispertion. However, it is obvious that it may cause problems in the future unless the necessary measures are taken. Therefore, tight control should be applied and sources of pollutants given to the Stream should be prevented.

\section{Author's Contributions}

All authors contributed equally to the study.

\section{Statement of Conflicts of Interest}

There is no conflict of interest among the authors.

\section{Statement of Research and Publication Ethics}

The authors declares that this study complies with Research and Publication Ethics.

\section{References}

[1] Hussien B. M., Rabeea M. A., Farhan M. M. 2020. Characterization and behavior of Hydrogen Sulfide plumes released from active sulfide-tar springs, Hit-Iraq. Atmospheric Pollution Research, 11 (5): 894-902. 
[2] Ulutaş K., Pekey H., Demir S., Dinçer F. 2017. Determinatıon of odor levels in wastewater treatment plants by olfactometric method. Dokuz Eylul University Faculty of Engineering Journal of Science and Engineering, 19 (57): 867-877.

[3] Woodall G. M., Smith R. L., Granville, G. C. 2005. Proceedings of the hydrogen sulfide health research and risk assessment symposium October 31-November 2, 2000. Inhalation toxicology, 17 (11): 593-639.

[4] Pavilonis B. T., O'Shaughnessy P. T., Altmaier R., Metwali N., Thorne P. S. 2013. Passive monitors to measure hydrogen sulfide near concentrated animal feeding operations. Environmental Science: Processes \& Impacts, 15 (6): 1271-1278.

[5] Moreno-Silva C., Calvo D. C., Torres N., Ayala L., Gaitán M., González L., Rincón P., Susa M. R. 2020. Hydrogen sulphide emissions and dispersion modelling from a wastewater reservoir using flux chamber measurements and AERMOD ${ }^{\circledR}$ simulations. Atmospheric Environment, 224: 117263.

[6] Ogbemudia F. O., Ita R. E. 2020. Assessment of Air Quality and Meteorological Variables in Lower Stubbs Creek, Qua Iboe River Estuary, Nigeria. World News of Natural Sciences, 28: 121130.

[7] Novita E., Pradana H. A., Purnomo B. H., Puspitasari A. I. 2020. River water quality assessment in East Java, Indonesia. Journal of Water and Land Development, 135-141.

[8] Odum E. P. 1997. Ecology: a bridge between science and society. Sinauer Associates Incorporated, Sunderland, 1-330.

[9] Huang J., Yın H., Chapra S.C., Zhou Q. 2017. Modelling dissolved oxygen depression in an urban river in China, Water, 9: 1-19.

[10] Water pollution from agriculture: A global review, Rome-Colombo, 2017. http://www.fao.org/3/i7754e/i7754e.pdf (Available: 29.02.2021).

[11] Toxicological review of hydrogen sulfide, 2003. EPA/635/R-03/005 Washington, DC https://cfpub.epa.gov/ncea/iris/iris_documents/documents/toxreviews/0061tr.pdf (Available: 29.02.2021).

[12] Guidotti T.L. 2010. Hydrogen sulfide: advances in understanding human toxicity, International journal of toxicology, 29 (6): 569-581.

[13] Guidotti T.L. 1996. Hydrogen sulfide, Occup Med., 46 (5): 367-371.

[14] Polat N. 2019. Araç çayı havzası'nın uygulamalı hidrografyası. Master Thesis, Karabük University, Karabük.

[15] Karabük'te toplu balık ölümleri, 2018. https://tv.haberturk.com/tv/burasiturkiye/video/karabukte-toplu-balik-olumleri-cok-sayida-balik-karaya-vurdu/496426 (Available: 29.02.2021).

[16] Çevre Durum Raporu, 2013. Çevre ve Şehircilik İl Müdürlügü, Karabük.

[17] Özen F. 2019. Evaluation of soil fertility in citrus planted areas by geostatistics analysis method. Eurasian Journal of Soil Science, (4): 351-363.

[18] Ölmez S.S. 2008. Odour control in wastewater treatment plants using ozonation and chemical scrubbing. (Master Thesis, Marmara University, Istanbul).

[19] Isworo S, Oetari P.S, Indah N.A. 2017. Water Quality Status of River Donan due to Operational Refinery Pertamina Unit IV Cilacap-Central Java-Indonesia. Asian Journal of Biology, 1-10.

20] Wiener M.S, Salas B.V, Quintero-Nunez M, Zlatev R. 2006. Effect of H2S on corrosion in polluted waters: a review. Corrosion engineering, science and technology, 41 (3): 221-227.

[21] Sawyer C.N, Mc Cartey T.L, Parkin G.S. 2003. Chemistry for Environmental Engineering, 5th edition.; Mc Graw-Hill Interntional Editions, New York, USA.

[22] Jesse L, Cristiane L, Michael A.J. 2015. AERMOD View User Guide, Lakes Environmental, Kanada.

[23] Antai R.E, Osuji L.C, Obafemi A.A, Onojake M. 2020. Assessment of Changes in Air Quality in Wet Season: A Case Study of Eleme, Rivers State, Nigeria, Journal of Environmental Science, Toxicology and Food Technology, 14 (5): 10-21.

[24] Muezzinoglu A. 2003. A study of volatile organic sulfur emissions causing urban odors. Chemosphere, 51 (4): 245-252.

[25] Muezzinoglu A, Odabasi M, Onat L. 2001. Volatile organic compounds in the air of İzmir, Turkey. Atmospheric Environment, 35 (4): 753-760. 
[26] Rim-Rukeh A. 2014. An assessment of the contribution of municipal solid waste dump sites fire to atmospheric pollution. Open Journal of Air Pollution, 3 (03): 53.

[27] Verma A, Kumar R, Yadav S. 2020. Distribution, pollution levels, toxicity, and health risk assessment of metals in surface dust from Bhiwadi industrial area in North India. Human and Ecological Risk Assessment: An International Journal, 26 (8): 2091-2111.

[28] Schiffman S.S, Bennett J.L, Raymer J.H. 2001. Quantification of odors and odorants from swine operations in North Carolina. Agricultural and Forest Meteorology, 108 (3): 213-240.

[29] Jeon E.C, Son H.K, Sa J.H. 2009. Emission characteristics and factors of selected odorous compounds at a wastewater treatment plant. Sensors, 9 (1): 311-326.

[30] Dincer F. 2007. Characteristic and Chemistry of Odors from Selected Industrial Facilities in Izmir (Doctoral dissertation, Ph. D Thesis, Dokuz Eylül University, İzmir).

[31] Koku Oluşturan Emisyonların Kontrolü Yönetmeliği. T.C Resmi Gazete. 19 Temmuz 2013 tarih, Say1:28712.

[32] Saral A, Demir S, Yıldız Ş. 2009. Assessment of odorous VOCs released from a main MSW landfill site in Istanbul-Turkey via a modelling approach. Journal of Hazardous Materials, 168 (1): 338-345.

[33] Rappert S, Müller R. 2005. Odor compounds in waste gas emissions from agricultural operations and food industries. Waste Management, 25 (9): 887-907. 